Institute of $\mathbf{F}_{\text {ood and }} \mathbf{A}$ gricultural $\mathbf{S}_{\text {ciences }}$

\title{
A Rationale for Further Herd Expansion on Florida Dairies ${ }^{1}$
}

Russell Giesy and Albert de Vries ${ }^{2}$

\section{Introduction}

Changing social, environmental, and economic circumstances generate pressure for future expansion on dairy farms in Florida. Several environmental activist groups have indicated concern about herd growth. They advocate fixing the current herd size of all dairies permanently. Yet, for as long as we have records of the number of dairy farms in the U.S., the trend toward fewer dairy farms has been consistent. As a result of declining numbers of farms, in a nation with a growing population and fairly static per-capita demand, growth in herd size has been and will be necessary.

\section{Consumer Demand}

Consumer demand will likely increase. The world's population surpassed 6 billion people in 1999 and increases by 70 to 80 million each year. With these trends in place, the population may exceed 9 billion by 2050. In addition, the diets of people have improved significantly and the average life expectancy has risen by a third since 1955 from 48 to 66 years. With this in mind, it is conceivable that the world will need to double its food production in the next two generations.
Florida is in a more precarious situation due to the rapid population growth and corresponding loss of farmland.

Fluid milk also has a relatively flat per-capita consumer demand index, suggesting that demand for fluid milk will increase as the population continues to grow. Other dairy products, cheese for example, continue to grow in consumer demand and popularity. Milk is a perishable product not easily or cheaply transported. With the increasing cost of energy, it becomes more important that milk be produced in Florida to meet consumer demand as econimcally as possible.

\section{Trend in Herd Size}

According to Don Blayney of the U.S.D.A., "Dairy farms continue to grow, become more concentrated in certain regions, and become more specialized in producing milk." In 1940, there were 4.66 million dairy farms. Of that number, only $68 \%$ remained in $1950,36 \%$ in $1964,18 \%$ in 1974 , and $2.3 \%$ in 2000 . A more recent report by Ken Olson indicates that the rate of decline in dairy farms has accelerated. Since 1992, 44\% of U.S. dairies have discontinued. However, $49 \%$ of dairies in

1. This document is AN133, one of a series of the Animal Sciences Department, Florida Cooperative Extension service, Institute of Food and Agricultural Sciences, University of Florida. Published November 2002. Please visit the EDIS Web Site at http://edis.ifas.ufl.edu.

2. Russell Giesy, Multi-County Dairy Agent and Albert de Vries, Assistant Professor, Department of Animal Sciences, University of Florida; Florida Cooperative Extension Service, Institute of Food and Agricultural Sciences, University of Florida, Gainesville, 32611. 
southeastern states discontinued. In 2002 alone, 5.5\% of Florida dairies sold out.

The dairy farm economy demands increasing efficiency. Penn State Professor Ken Bailey, also a nationally recognized milk marketing expert, reported that "First, to keep ahead of inflation, dairy farms must increase milk sales every year in order to have sufficient profits to live on. Second, no business can continue if they require a large investment and realize low sales." Only two techniques are available to producers, increasing herd size or increasing milk per cow. Of 105,250 U.S. dairy herds in $2000,35.8 \%$ had 500 or more cows. Herds of over 200 cows grew during this period (1992-2001) by $14.3 \%$ and in 2001 , accounted for $57 \%$ of the total production.

\section{Reasons for Herd Expansion on Florida Dairies}

- Pay for environmental regulations. Nutrient handling systems do not generate revenues sufficient to pay the cost of investment. In fact, nearly all projections that are used to solicit loans for new barns or equipment include an expenditure for additional cows. Why? Cows produce the revenues that pay for investments, most other assets do not.

History shows that new policies that require significant investments in non-productive assets result in a loss of dairy farms. The total number of Florida dairy farms is about 205 in mid-2002. The average age of the owner/operators of those farms is about 56. Thus, producers nearing retirement age, many without another generation interested in dairy farming in the future, will look closely at further investments. A rather recent example is the Okeechobee environmental situation of the late1980's. Of 47 dairies located in the Okeechobee drainage basin in 1987, only 23 operate today. Fifty percent of dairies moved, retired or tried unsuccessfully to operate after making new investments. Boggess, et al reported the additional cost of those investments accrued to $\$ 1.10$ per cwt for ten years. Further, the economic loss was felt throughout the community as fewer people were employed, less feed and supplies purchased, etc. Giesy, et al. reported that the cost of implementing and operating new manure handling systems on eight
Central Florida dairies in 1998 increased their cost of production up to $\$ .60$ per cwt.

John Folks of the Florida Department of Agriculture and Consumer Services estimated new costs of large dairies that will need to meet phosphorous budgets. These estimates included confinement housing, testing of all feedstuffs, established grazing densities at below agronomic rates, optimized nutrient applications, capture and recycling of nutrients and water, captured storm-water, and edge-of-farm treatment systems. The resulting calculations suggested an investment of $\$ 2.76$ million per dairy or $\$ 1,840$ per cow for 1,500 cows. However, when estimates for housing and other system enhancements for an additional 1,500 cows were added, the total cost of the system was $\$ 3.54$ million or $\$ 1,178$ per cow. The cost per cow, the productive unit, was reduced by $46 \%$ by adding the additional cows.

The University of Florida's Dairy Business Analysis Program, DBAP, has determined that farm income per cwt averaged $\$ 1.30$ from 1995-2001. That margin was used to pay federal income tax and any unpaid family labor. It also must provide for family living and a return on invested capital. \$1.30 was an average level, and about half of DBAP participants had net incomes per cwt below that level.

A 2002 University of Florida preliminary study has estimated costs of planning, implementing, operating, and replacing equipment used in nutrient handling systems with the newest technology to bind, remove, or control phosphorus. These costs were estimated at $\$ .60$ to $\$ .70$ per cwt. Since the first of these systems has been recently installed (mid-2002), these estimates are very much uncertain. However, the question then is that if producers understand that their margin will be cut in half, will they commit to the future and implement these systems? Because of their age and demand for land for development, many are likely to retire. Those that do commit to continue, will see margins per cwt reduced, thus will increase herd size to generate more cwts.

The federal government has recognized that the U.S. dairy industry is at a crossroads. As the EPA implemented new regulations, congress reacted with provisions in the 2002 Farm Bill providing for 
Environmental Quality Incentives Program funding to help producers implement systems. Wisconsin's state legislature is providing a $\$ 500$ per cow motivation to Wisconsin's producers willing to expand their herd size. New York state has passed legislation to enhance the milk price to its producers.

- Gain productive efficiency. According to DBAP, labor was used more efficiently on large dairies ( $>1000$ cows). They produced about $10 \%$ more milk per worker. Small dairies ( $<500$ cows) produced about .9 million pounds, larger dairies, over 1.0 million pounds per worker. Cows were used more efficiently as well, production rates per cow on the larger dairies was 19,009 pounds, compared to 15,475 pounds on the smaller dairies.

Studies by Cornell University and Northeast Farm Credit indicated that larger farms were more profitable. They produced more milk per cow at a lower cost per cwt and used fewer assets to generate a dollar of revenue. Further, they received higher premiums for milk quality and volume.

Florida dairies that have shown growth in total production volume of 3-5\% per year have been the most profitable of dairies that have participated in DBAP, over time. When growth is not apparent, management must be concerned about obsolescence, a cancer of any business or industry.

- Gain economies of scale. Larger dairies can purchase commodities in greater volume. Purchased feed expense per cwt. on the larger DBAP2000 dairies was $\$ 7.41$ compared to the $\$ 8.15$ cost on smaller dairies. Of course, part of this difference is related to the productive efficiency mentioned above. Another sign of economic efficiency is asset turnover rate, or atr. This measures how efficiently the assets of a dairy are utilized to generate revenues. Of the DBAP dairies, the larger group had an atr of .92 compared to .59 for the smaller dairies. This seems logical since it is commonly believed that larger dairies have the opportunity to spread depreciation costs of fixed assets over more cows and cwts of milk.

- Improve lifestyle. Members of farm families, especially on smaller dairies where everyone is part of the labor force, can be tied to the farm. That makes quality family time, like vacations, difficult to manage. Larger dairies can provide owner operators and their families time away. Also, large dairies generally employ herds-persons and other middle management people that can impact productivity.

- Include family members. Generally, the only way to add a son or daughter to a small family farm is to expand its herd size. One of the common goals of farm families is to sustain a family business and family tradition across generations.

- Consumer demand. Dairy farms do not produce adequate quantities of milk to satisfy the increasing demand of a growing population in Florida. Thus, increasingly, milk must be imported at greater cost (transportation) and sacrifice of quality (older milk). It is in the best interest of Florida consumers that milk be produced here. In the longer run, what is best for the consumer is best for the producer as well.

\section{Dairies are Becoming Environmentally Friendly}

Large dairies are required to record nutrient flows, enabling monitoring of practices. University of Florida Agricultural Engineering Professor Roger Nordstedt reported that "regulatory agencies enact rules which prevent problems with practices which only are perceived to have the potential for creating an environmental problem...Although these rules and regulations have good intent, they can result in substantial costs to dairy farmers and consumers."

Ron St John, owner of a large dairy farm, indicated that "Planning future expansion has two parts. First and foremost is the environment. This aspect is very new to the dairy industry, but in the future it could have a greater impact than any other item. If the people of this country want cheap food, politicians must be made to understand the ramifications of all rules being considered..."

New technologies are being utilized on several dairies in efforts to meet the demand to balance nutrients. Significant investments have and will be made to advance the current state of compliance. Record keeping systems and reporting mechanisms have been developed to help improve the understanding of nutrient flows. Opportunities for 
cost sharing have increased, recognizing the fact that most, perhaps all, of these new systems will increase the cost of production for dairies that implement them. Because the costs of the mandated improvements cannot be directly passed on to consumers without pricing the milk our of the reach of many people, dairies would have to share costs to keep milk and other nutritious dairy foods available to Florida's families.

\section{Summary}

Environmental theorist W.D. Ruckelshaus wrote, "Sustainability is the doctrine that economic growth and development must take place, and be maintained over time, within the limits set by ecology in the broadest sense by the interrelations of human beings and their works, and the biosphere. It follows that environmental protection and economic development are complimentary rather than antagonistic processes."

It is critical that Florida dairy farms continue to be able to increase the size of their herds to maintain profitability after investing in new technologies and management systems to respond to (1) environmental regulatory action, (2) the economic trends in place in an industry that demands enhanced efficiency, and (3) increasing needs of food production capability for a rapidly growing population. Setting a maximum herd size for a dairy would make every Florida dairy farm obsolete, with little hope for regaining productive or economic efficiency. It is likely that the best interest of the people of Florida will be served by a strong dairy farm economy, in concert with continued and very rapid implementation of newer technologies that make dairy farms environmentally friendly.

\section{References}

Bailey, Ken. 2002. U.S. market structure: the dairy industry in the $21^{\text {st }}$ century. Penn State University, State College, PA.

Bailey, Ken. 2002. Opportunities for success on small dairy farms revisited. Penn State University, State College, PA.
Blayney, D.P. 2002. The changing landscape of U.S. milk production. Statistical bulletin 978, United State Department of Agriculture, Washington, D.C.

Folks, J. 2002. Whole farm nutrient management practices/actions for worst world dairy. Florida Department of Agriculture, Tallahassee, FL.

Giesy, DeVries, Vullings, Nordstedt, Miller, Broaddus, Vann and Seawright. 2002. Economic feasibility of new technologies for nutrient handling systems on Florida dairies. University of Florida Extension Service, Gainesville, FL.

Giesy, DeVries, Miller, Broaddus, Vann, Seawright, Andreasen, Ely, Eubanks and Dearaujo. 2002. DBAP: analysis of selected factors across seven years. University of Florida Extension Service, Gainesville, FL.

Giesy, R. 1999. Economic impact of environmental regulation on the Florida dairy industry. University of Florida Extension Service, Gainesville, FL.

Giesy, R.G., H.H. Van Horn, M.A. DeLorenzo, L.T.G. ten Brooke, N.C.C.F. Mureau and M.J. Hoekema. 1999. Nutrient handling systems on Florida dairies: identifying costs and returns. University of Florida Extension Service, Gainesville, FL.

Henry, Steve D.V.M. 2002. Meeting future challenges for producing pork in a rapidly changing world. Swine Practitioner. September 2002. A Vance publication, Skokie, IL.

Nordstedt, R.A. 1992. Selecting a waste management system. Large Dairy Herd Management. American Dairy Science Association, Champaign, IL.

Olson, K.E. 2002. Dairy farm numbers drop to 74,012. Hoards Dairyman, October 25, 2002 issue. Fort Atkinson, WI.

Ruckelshaus, W.D. 1989. A definition of sustainability. Scientific American. Captured and down-loaded from the web-site Florida Sustainable Communities Center Resources. 
St John, R. 1992. Planning and budgeting for a new dairy unit and financing expansion. Large Dairy Herd Management. American Dairy Science Association, Champaign, IL.

Van Horn, H.H. G.L. Newton, G. Kidder and E.C. French. 1996. Managing dairy manure accountably: worksheets for nutrient budgeting. University of Florida Extension Service, Gainesville, FL.

Webb, D.W., A. DeVries, R. Giesy, and L. Ely. 2001. Dairy Business Analysis Summary. University of Florida Extension Service, Gainesville, FL. 